\title{
ANALISIS KEMAMPUAN PENALARAN MATEMATIS SISWA KELAS VIII SMP NEGERI 5 KENDARI DITINJAU DARI PERSPEKTIF GENDER
}

\author{
Risman Alifin $^{I)}$, Kodirun $^{2)}$, Ikman $^{3)}$ \\ ${ }^{1)}$ Alumni Jurusan Pendidikan Matematika, ${ }^{2,3}$ Dosen Jurusan Pendidikan Matematika \\ FKIP Universitas Halu Oleo Email: alifinrisman@gmail.com, kodirun_zuhry@yahoo.co.id, \\ ikman_fkipmat@yahoo.com
}

\begin{abstract}
Abstrak
Penelitian ini bertujuan untuk mendeskripsikan kemampuan penalaran matematis siswa kelas $\mathrm{VIII}_{\mathrm{C}}$ SMP Negeri 5 Kendari ditinjau dari perspektif gender. Penelitian ini adalah penelitian deskriptif yang menggunakan data kuantitatif dan kualitatif. Teknik pengambilan subjek dalam penelitian ini menggunakan teknik Purposive Sampling. Subjek dalam penelitian ini adalah 31 siswa kelas VIII $_{\mathrm{C}}$ SMP Negeri 5 Kendari tahun ajaran 2018/2019 dan dilakukan pada bulan September-Oktober 2018. Teknik pengumpulan data dalam penelitian ini dilakukan dengan pemberian instrumen penelitian berbentuk tes uraian dan wawancara. Teknik analisis data berupa analisis hasil tes kemampuan penalaran dan wawancara terkait kemampuan penalaran matematis siswa dengan menggunakan tahap penalaran menurut Polya. Berdasarkan hasil analisis data diperoleh kesimpulan bahwa subjek perempuan memiliki kemampuan penalaran matematis yang lebih tinggi dibandingkan subjek lakilaki. Hal ini ditunjukkan dengan nilai rata-rata kemampuan penalaran matematis subjek perempuan lebih tinggi dibandingkan dengan nilai rata-rata kemampuan penalaran matematis siswa laki-laki.
\end{abstract}

Kata Kunci: kemampuan penalaran, gender, tahap penalaran menurut polya.

\section{AN ANALYSIS OF STUDENTS' MATHEMATICAL REASONING ABILITY OF CLASS VIII $_{C}$ SMP NEGERI 5 KENDARI IN TERM OF GENDER PERSPECTIVE}

\begin{abstract}
This study aims to describe the students' mathematical reasoning ability of class VIII $\mathrm{C}_{\mathrm{C}}$ SMP Negeri 5 Kendari in term of gender perspective. This study is descriptive study which using quantitative and qualitative data. Sampling technique in this study is using purposive sampling. Subjects in this study are 33 students of class VIII SMP Negeri 5 Kendari academic year 2018/2019 and conducted in September-October 2018. Technique of data collection is done by giving the study instrument in the form of essay test and interview. Data analysis techniques use analysis of result tests' mathematical reasoning ability and interview related to the students' mathematical reasoning ability by using reasoning step according to Polya. Based on the results of data analysis obtained the conclusion that the female subjects has mathematical reasoning ability higher than male subject. This is indicated by the average value of the female subjects' mathematical reasoning ability which is higher than the average value of the male subjects' mathematical reasoning ability.
\end{abstract}

Keywords: reasoning ability, gender, step of reasoning according to polya. 


\section{Pendahuluan}

Belajar merupakan suatu proses atau usaha sadar yang dilakukan individu untuk memperoleh suatu perubahan tingkah laku yang baru secara keseluruhan sebagai hasil pengalaman individu itu sendiri dalam berinteraksi dengan lingkungan. Sekolah sebagai lembaga formal merupakan sarana dalam rangka pencapaian tujuan pendidikan tersebut. Belajar menunjukkan adanya perubahan yang sifatnya positif sehingga pada tahap akhir akan didapat keterampilan, kecakapan dan pengetahuan baru. Supaya tampil unggul pada keadaan yang selalu berubah dan kompetitif ini, manusia Indonesia dituntut perlu memiliki kemampuan memperoleh, memilah dan mengolah informasi. Begitu pula dengan kemampuan untuk dapat berpikir kritis, sistematis, logis, analitis, kreatif dan kemampuan untuk dapat bekerja sama secara efektif. Sikap dan cara berpikir seperti ini dapat dikembangkan melalui proses pembelajaran matematika.

Matematika adalah salah satu cabang ilmu pengetahuan eksak yang menjadi ratu bagi ilmu pengetahuan lain. Oleh karena itu, matematika memiliki peranan penting dalam pengembangan pendidikan baik dalam pendidikan formal maupun non formal. Matematika mempelajari tentang pola keteraturan dan struktur yang terorganisasi. Matematika dapat diterapkan dalam berbagai aspek kehidupan manusia dari yang paling sederhana sampai hal yang kompleks. Misalnya saja seseorang yang ingin berbelanja kebutuhan sehari-hari, orang tersebut tentu harus mengeluarkan sejumlah uang untuk membeli barang kebutuhannya. Untuk memperkirakan sejumlah uang yang akan terpakai, maka orang tersebut harus mengkalkulasi dengan perhitungan sederhana. Permasalahan kompleks yang memerlukan matematika misalnya jika seorang ahli teknologi akan membuat program atau aplikasi tertentu, maka harus melalui proses pengkodingan program tersebut dengan memanfaatkan konsep matematika yaitu logika matematika dan algoritma matematika.

Matematika memiliki struktur dan keterkaitan yang kuat dan jelas antara konsepnya sehingga memungkinkan siapapun yang mempelajarinya akan memiliki keterampilan berpikir secara rasional. Sejalan dengan itu, matematika juga digunakan sebagai alat ukur menentukan kemajuan pendidikan di suatu negara. Melalui survei yang digagas oleh Programme International for Student Assessment (PISA) pada tahun 2015 bersama organisasi kerjasama dan pengembangan ekonomi dunia OECD (Organization for Economic Cooperation and Development) menunjukkan bahwa rata-rata skor kemampuan literasi matematika siswa Indonesia hanya mencapai 386 atau hanya mencapai level 1 dari 6 level yang ditetapkan. Dengan hasil ini berarti Indonesia menempati posisi 8 negara terbawah dari 70 negara peserta (OECD, 2016: 5). Hasil ini menunjukkan bahwa kemampuan literasi matematis siswa Indonesia masih tergolong rendah. Padahal kemampuan literasi matematis seorang siswa juga dibentuk oleh kemampuan penalaran matematis yang dimilikinya. Ini berarti kemampuan penalaran matematis siswa juga menjadi salah satu aspek penilaian PISA dalam mengukur kemampuan literasi siswa suatu negara. Melalui PISA (Program for International Student Assessment) dan TIMSS (The International Mathematics and Science Survey) yang secara berkala membandingkan dan mengukur kemajuan pendidikan matematika di beberapa Negara, kita dapat mengetahui tingkat kemampuan matematika siswa di Indonesia.

Sangat banyak fakta di lapangan yang menunjukkan bahwa prestasi belajar matematika Indonesia di kancah internasional masih tergolong rendah. Hasil penelitian yang juga dilakukan oleh Association for the Evaluation of Educational Achievement (IEA) pada tahun 2011 menempatkan siswa Indonesia pada peringkat 38 dari 45 negara yang ikut berpartisipasi (Mullis, Ina V.S, Martin, O. Michael \& Foy Pierre, 2012: 42). Ini berarti Indonesia menempati 8 posisi negara terbawah. Prestasi ini berada jauh di bawah negara-negara ASEAN yang berpartisipasi, seperti Thailand yang menempati posisi ke 28, Malaysia di peringkat ke 26, dan Singapura yang menempati peringkat ke 2. Hasil ini seakan memotivasi pemerintah untuk berupaya keras meningkatkan prestasi belajar matematika siswa Indonesia.

Menurut Asikin (Rofiqoh, 2015: 2), belajar matematika di sekolah memiliki beberapa tujuan yaitu: (1) mengorganisasikan logika penalaran siswa dan membangun kepribadiannya, dan (2) membuat siswa agar mampu memecahkan (National Council of Teachers of Mathematics) sebagaimana dikutip 
oleh Effendi, (2012: 2), menetapkan lima standar kemampuan matematis yang harus dimiliki oleh siswa, yaitu kemampuan pemecahan masalah (problem solving), kemampuan komunikasi (communication), kemampuan koneksi (connection), kemampuan penalaran (reasoning), dan kemampuan representasi (representation). Tujuan pembelajaran matematika dan standar dari NCTM yaitu salahsatunya agar peserta didik memiliki kemampuan menggunakan penalaran pada pola dan sifat, melakukan manipulasi matematika dalam membuat generalisasi, menyusun bukti atau menjelaskan gagasan dan pernyataan matematika (Ario, 2016: 1). Hal ini menunjukkan bahwa kemampuan penalaran matematis merupakan kemampuan yang penting dan harus dimiliki oleh siswa serta tidak dapat dipisahkan dari matematika.

Menyadari hal itu, Peraturan Menteri Pendidikan dan Kebudayaan (Permendikbud) Nomor 58 Tahun 2014 tentang kurikulum SMP sebagaimana kutipan Putranto pada tahun 2016, menegaskan bahwa salah satu tujuan matematika pada kurikulum 2013 adalah agar siswa mampu menggunakan penalaran, melakukan manipulasi matematika baik penyederhanaan maupun menganalisa komponen pemecahan masalah, baik dalam konteks matematika maupun di luar matematika (kehidupan nyata, ilmu, dan teknologi), yang meliputi kemampuan memahami masalah, membangun model matematika, menyelesaikan model dan menafsirkan solusi yang diperoleh termasuk dalam rangka memecahkan masalah dalam kehidupan sehari-hari. Hal ini berarti pemerintah menaruh perhatian khusus pada upaya peningkatan kemampuan penalaran matematis siswa Indonesia. Upaya ini dilakukan agar prestasi belajar siswa Indonesia dapat bersaing di kancah internasional.

Lemahnya kemampuan penalaran matematis siswa dapat dicermati melalui The Trends in International Mathematics and Science Study (TIMMS) yang menjelaskan bahwa perkembangan domain kognitif khususnya kemampuan penalaran (reasoning) Indonesia menurun dari tahun 2007 ke tahun 2011, pada tahun 2011 skor rata-rata Indonesia 386 sedangkan tahun 2007 skor rata-ratanya 393 sehingga perbedaan skor rata-rata Indonesia antara tahun 2007 dan 2011 adalah 7 poin. Semua data diatas menjelaskan lemahnya kemampuan penalaran matematis siswa
Indonesia, tak terkecuali pada siswa kelas $\mathrm{VIII}_{\mathrm{C}}$ SMP Negeri 5 Kendari.

Secara spesifik memang fakta di lapangan menunjukkan bahwa secara umum siswa belum memiliki kemampuan penalaran matematis yang baik. Siswa sering tidak memahami makna sebenarnya dari permasalahan yang diberikan oleh guru, khususnya soal-soal yang diberikan dalam bentuk soal cerita yang kontekstual. Padahal idealnya siswa sebagai seorang manusia yang selalu bergelut dengan masalah-masalah dalam kehidupannya harus lebih mampu memahami permasalahan matematika yang disajikan secara kontekstual. Begitupun yang dialami oleh siswa kelas VIII ${ }_{C}$ SMP Negeri 5 Kendari.

Berdasarkan pengamatan di salah satu lembaga bimbingan belajar di kota Kendari yang lebih dari 50\% siswa jenjang SMPnya berasal dari SMP Negeri 5 Kendari, diperoleh fakta bahwa kemampuan penalaran matematis siswa masih tergolong kurang. Sebagian besar siswa di sana mengalami kesulitan atau kurang mahir dalam menyelesaikan soal matematika, khususnya soal yang diberikan dalam bentuk cerita yang berhubungan langsung dengan kehidupan sehari-hari (kontekstual). Siswa cenderung lebih cepat dalam menyelesaikan soal-soal sederhana yang hanya langsung menggunakan rumus dan perhitungan tanpa menggunakan langkah prosedural dari penyelesaian masalah matematis siswa sesuai langkah Polya.

Berdasarkan wawancara singkat peneliti dengan salah satu guru matematika kelas VIII $_{C}$ SMP Negeri 5 Kendari juga diperoleh hasil bahwa pada umumnya siswa cenderung menghafal rumus sehingga dalam menyelesaikan suatu masalah matematika yang diberikan, siswa lebih terfokus pada buku saja, sehingga siswa sulit memunculkan ide-ide baru dalam menyelesaikan masalah tersebut, khususnya soal matematika yang berkaitan dengan kehidupan sehari-hari.

Meningkatkan kemampuan penalaran matematis bukan hanya menjadi tanggungjawab pemerintah, tetapi juga tanggung jawab guru. Salahsatu upaya yang dilakukan pemerintah adalah pengembangan kurikulum dalam memperbaiki kualitas pendidikan di Indonesia. Kurikulum yang telah diterapkan di Indonesia saat ini adalah kurikulum 2013. Kurikulum 2013 adalah kurikulum yang melakukan penyederhanaan dan tematik-integratif, serta 
menambah jam pelajaran yang bertujuan untuk mendorong siswa agar mampu melakukan observasi, bertanya, bernalar dan mengkomunikasikan apa yang mereka peroleh atau mereka ketahui setelah menerima materi pelajaran. Dalam kurikulum 2013 dinyatakan bahwa mata pelajaran matematika perlu diberikan kepada semua siswa mulai dari sekolah dasar untuk membekali siswa kemampuan berpikir logis, analitis, sistematis, kritis, dan kreatif, serta kemampuan bekerjasama.

Rendahnya kemampuan penalaran matematis siswa tentunya disebabkan oleh banyak faktor. Berdasarkan uraian diatas, peneliti menduga adanya hubungan antara kemampuan penalaran matematis dan gender karena penalaran merupakan aktivitas berpikir. Hal ini sejalan dengan apa yang diungkapkan Santrock (Afandi, 2016: 11) tentang peran gender yaitu suatu kumpulan harapan yang menetapkan bagaimana perempuan atau laki-laki harus berpikir, bertindak, dan berperasaan. Aktivitas berpikir yang digunakan manusia untuk berpikir adalah otak, dimana otak tersebut memiliki perbedaan antara otak laki- laki dan otak perempuan. Seperti yang telah dijelaskan oleh Michel Gurian (Afandi, 2016: 11) yang mengatakan bahwa perbedaan antara anak lakilaki dan perempuan memang ada akibat perbedaan dalam otak mereka. Sedangkan Kartini Kartono (Afandi, 2016: 11) berpendapat bahwa betapapun baik dan cemerlangnya intelegensi perempuan, pada intinya perempuan hampir-hampir tidak pernah mempunyai ketertarikan yang menyeluruh pada soal-soal teoritis seperti laki-laki, perempuan lebih tertarik pada hal-hal yang praktis dari pada teoritis, perempuan juga lebih dekat pada masalahmasalah kehidupan praktis yang konkret, sedangkan laki-laki lebih tertarik pada segi-segi yang abstrak. Hal Ini sejalan dengan penelitian yang dilakukan oleh Rina Elok Siswanti pada tahun 2016, memperoleh hasil bahwa salahsatu faktor yang menyebabkan tinggi rendahnya kemampuan penalaran matematis siswa adalah perbedaan gender. Begitu pula penelitian yang dilakukan oleh Tri Sumartini pada tahun 2017 yang menyimpulkan bahwa terdapat hubungan dengan tingkat korelasi yang rendah antara perbedaan gender dengan kemampuan analisis matematis, dan terdapat perbedaan yang signifikan antara kemampuan siswa laki-laki dan perempuan dalam hal kemampuan analisis.

Hasil studi PISA juga menunjukkan dari beberapa negara performa laki-laki cenderung lebih unggul daripada perempuan. Hal ini dapat dilihat pada data yang didapatkan pada studi PISA 2006 dan 2009. Pada studi PISA tahun 2006 (OECD, 2007: 54) laki-laki lebih unggul pada 35 negara dari jumlah negara keseluruhan yaitu 57 negara yang ikut berpartisipasi. Pada 21 negara yang ikut berpartisipasi, menunjukkan tidak adanya perbedaan antara laki-laki dan perempuan, selebihnya perempuan lebih unggul daripada laki-laki. Sedangkan pada studi PISA tahun 2009 (OECD, 2010: 137) dari keseluruhan 65 negara yang berpartisipasi ada 35 negara yang cenderung menguntungkan untuk siswa laki-laki dan 5 negara yang cenderung dominan pada perempuan, dan 30 negara yang ikut berpartisipasi tidak menunjukkan perbedaan yang signifikan pada siswa laki-laki dan perempuan.

Kecenderungan siswa laki-laki lebih unggul dibanding dengan siswa perempuan ini berkaitan dengan aspek kejiwaan. Seperti pada ungkapan Qurotu, dkk. (Kurniawaty, 2017: 6) yang menyebutkan bahwa: (1) betapapun baik dan cemerlangnya intelegensi perempuan, namun pada intinya perempuan hampir tidak mempunyai ketertarikan yang menyeluruh pada soal-soal yang teoritis seperti kaum laki-laki dan (2) kaum wanita itu lebih praktis, lebih langsung dan meminati segi-segi kongkret. Kaum wanita tertarik pada kehidupan berumah tangga, kehidupan sehari-hari dan kejadian-kejadian yang berlangsung disekitar rumah tangganya. Sedangkan kaum pria pada umumnya hanya mempunyai ketertarikan pada latar belakang teoritis dengan minatnya atau terkait dengan dirinya sendiri. Secara ringkas, wanita lebih dekat pada masalah-masalah kehidupan yang praktis dan kongkret, sedangkan laki-laki lebih tertarik pada segi-segi kejiwaan yang bersifat abstrak.

Beberapa penelitian menunjukkan bahwa perempuan lebih labil daripada laki-laki yang pada umumnya stabil. Faktanya, dalam situasi dimana anggota kelompok (laki-laki dan perempuan) perbedaan gender dalam kemampuan matematika dapat dilihat yakni, siswa laki-laki lebih bagus dalam perhitungan pengukuran, sains dan olahraga. Sedangkan 
siswa perempuan lebih bagus dalam perhitungan yang berhubungan dengan tugas-tugas tradisional perempuan, seperti memasak dan menjahit. Ini berarti perbedaan gender sangat mempengaruhi prestasi belajar matematika siswa. Berdasarkan uraian tersebut, peneliti tertarik untuk mengadakan penelitian tentang kemampuan penalaran matematis siswa dengan judul "Analisis Kemampuan Penalaran Matematis Siswa Kelas VIII $_{C}$ SMP Negeri 5 Kendari Ditinjau dari Perspektif Gender".

\section{Metode}

Jenis penelitian yang digunakan dalam penelitian ini adalah penelitian deskriptif kualitatif yaitu penelitian yang digunakan untuk menggambarkan, menjelaskan dan menjawab persoalan-persoalan tentang fenomena dan peristiwa yang terjadi saat ini, baik tentang fenomena sebagaimana adanya maupun analisis hubungan antar variabel dalam suatu fenomena. Dalam penelitian ini akan dideskripsikan kemampuan penalaran matematis ditinjau dari perspektif gender.

Penelitian ini dilaksanakan di SMP Negeri 5 Kendari yang beralamat di Jln. Gersamata, Kel. Anduonohu, Kec. Poasia. Anduonohu, Kota Kendari, Provinsi Sulawesi Tenggara. Waktu pelaksanaannya pada semester ganjil yakni tahun ajaran 2018/2019 mulai tanggal 13 September 2018 sampai tanggal 2
Oktober 2018. Penelitian ini dilakukan pada siswa kelas VIII C SMP Negeri 5 Kendari semester ganjil tahun ajaran 2018/2019 yang terdistribusi pada 11 kelas paralel yaitu dari kelas $\mathrm{VIII}_{\mathrm{A}}$ sampai $\mathrm{VIII}_{\mathrm{K}}$. Berdasarkan informasi dari guru matematika, penyebaran siswa di setiap kelas paralel tidak dibedakan berdasarkan tingkat kemampuan matematikanya. Oleh karena itu, untuk keperluan penelitian ini akan dipilih 1 kelas sebagai sasaran penelitian. Pemilihan kelas sebagai subjek penelitian dilakukan secara purposive sampling yakni dengan pertimbangan mengambil kelas yang jumlah siswa laki-laki dan siswa perempuannya relatif sama. Dari cara tersebut diperoleh kelas VIII $_{C}$ sebagai subjek penelitian dengan jumlah siswa sebanyak 31 orang yang terdiri dari 15 siswa perempuan dan 16 siswa laki-laki.

Instrumen yang digunakan dalam penelitian ini adalah soal tes tertulis terkait kemampuan penalaran matematis dan pedoman wawancara.

Dalam penelitian ini diadakan satu kali tes yaitu tes tertulis terkait kemampuan penalaran matematis. Soal tes tertulis yang disusun juga dilakukan pengujian validitas menggunakan validitas isi, yakni dengan menggunakan pendapat dari ahli atau panelis (judgement experts) dan pengujian reliabilitas. Kisi-kisi tes tertulis terkait kemampuan penalaran matematis dapat dilihat pada Tabel 1.

Tabel 1

Kisi-Kisi Tes Kemampuan Penalaran Matematis

\begin{tabular}{|c|c|c|c|c|}
\hline $\begin{array}{c}\text { Pokok } \\
\text { Bahasan }\end{array}$ & $\begin{array}{c}\text { Kompetensi Dasar } \\
\text { (KD) }\end{array}$ & $\begin{array}{c}\text { Indikator } \\
\text { Kemampuan } \\
\text { Penalaran Matematis }\end{array}$ & $\begin{array}{c}\text { Nomor } \\
\text { Soal }\end{array}$ & $\begin{array}{c}\text { Jumlah } \\
\text { Soal }\end{array}$ \\
\hline $\begin{array}{l}\text { 1. Pola } \\
\text { bilangan }\end{array}$ & 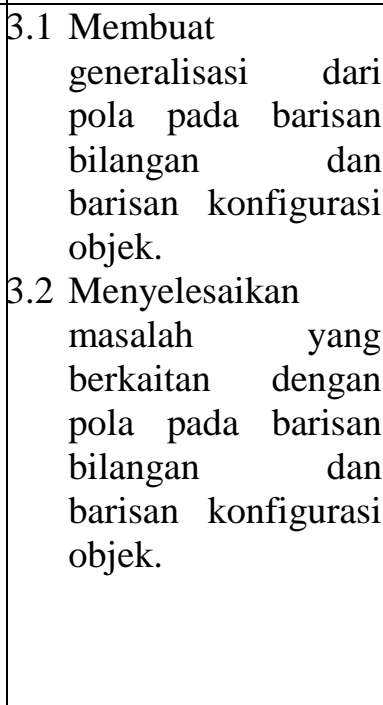 & $\begin{array}{rlr}\text { 1. } & \text { Menyajikan } \\
& \text { pernyataan } \\
& \text { matematika secara } \\
& \text { lisan, tertulis, } \\
& \text { gambar dan } \\
\text { diagram. } & \\
\text { 2. } & \text { Menemukan pola } \\
& \text { atau sifat dari gejala } \\
& \text { matematis untuk } \\
& \text { membuat } \\
& \text { generalisasi. } \\
\text { 3. } & \text { Memperkirakan } \\
& \text { jawaban dan proses } \\
& \text { solusi. } \\
\text { 4. } & \text { Menarik } \\
\text { kesimpulan logis. }\end{array}$ & 1,5 & 8 \\
\hline
\end{tabular}


Wawancara dengan siswa dimaksudkan untuk mengkonfirmasi ulang proses pengerjaan tes tertulis dari subjek penelitian sehingga dapat diketahui lebih lanjut terkait cara atau pola berpikir subjek terhadap kemampuan penalaran matematis dari soal tes tertulis yang telah diberikan. Peneliti melakukan wawancara kepada 8 orang perwakilan siswa kelas VIII $_{C}$ yakni 4 orang laki-laki dan 4 orang perempuan. Jenis wawancara yang dilakukan adalah wawancara tidak terstruktur dengan menggunakan pedoman wawancara yang mencakup garis besar pertanyaan yang disampaikan peneliti kepada siswa. Terdapat lima garis besar pertanyaan yang telah dirumuskan oleh peneliti. Dimulai dari siswa yang diminta untuk menjelaskan proses generalisasi untuk memperkirakan jawaban hingga menarik kesimpulan.
Walaupun demikian, kegiatan wawancara tidak hanya berpusat pada lima garis besar pertanyaan yang telah dirumuskan, dalam artian jika dalam kegiatan wawancara ada jawaban siswa yang memunculkan permasalahan baru dan berkaitan dengan penelitian, maka peneliti dapat menyampaikan pertanyaan baru yang belum disediakan. Pedoman wawancara yang disusun juga dilakukan pengujian validasi secara konstruk, dengan menggunakan pendapat dari ahli (judgement experts). Dalam artian setelah instrumen selesai disusun maka selanjutnya dikonsultasikan dengan para ahli yaitu dosen pembimbing atau pakar dan guru mata pelajaran matematika di SMP Negeri 5 Kendari. Kisi-kisi pedoman wawancara dengan siswa dapat dilihat pada Tabel 2.

Tabel 2

Kisi-Kisi Pedoman Wawancara

\begin{tabular}{|c|c|}
\hline $\begin{array}{l}\text { Indikator Penalaran } \\
\text { Matematis }\end{array}$ & Pertanyaan \\
\hline \multirow{3}{*}{$\begin{array}{l}\text { Menyajikan pernyataan } \\
\text { matematika secara lisan, } \\
\text { tertulis gambar dan } \\
\text { diagram }\end{array}$} & $\begin{array}{l}\text { Apa saja yang diketahui dan ditanyakan dari soal tersebut? } \\
\text { Coba jelaskan! }\end{array}$ \\
\hline & $\begin{array}{l}\text { Apakah kamu menemukan kesulitan dalam memahami } \\
\text { unsur-unsur yang diketahui dan ditanyakan dari soal } \\
\text { tersebut? Coba jelaskan! }\end{array}$ \\
\hline & $\begin{array}{l}\text { Bagaimana cara kamu menyajikan jawaban terhadap soal } \\
\text { yang diberikan?Coba jelaskan! }\end{array}$ \\
\hline \multirow{3}{*}{$\begin{array}{l}\text { Menemukan pola atau } \\
\text { sifat dari gejala } \\
\text { matematika untuk } \\
\text { membuat generalissasi }\end{array}$} & $\begin{array}{l}\text { Apa saja yang diketahui dan ditanyakan dari soal tersebut? } \\
\text { Coba jelaskan! }\end{array}$ \\
\hline & $\begin{array}{l}\text { Apakah kamu menemukan kesulitan dalam memahami } \\
\text { unsur-unsur yang diketahui dan ditanyakan dari soal } \\
\text { tersebut? Coba jelaskan! }\end{array}$ \\
\hline & $\begin{array}{l}\text { Bagaimana cara kamu mengetahui pola yang terdapat dalam } \\
\text { soal?Coba jelaskan! }\end{array}$ \\
\hline \multirow{3}{*}{$\begin{array}{l}\text { Memperkirakan jawaban } \\
\text { dan proses solusi }\end{array}$} & $\begin{array}{l}\text { Apa saja yang diketahui dan ditanyakan dari soal tersebut? } \\
\text { Coba jelaskan! }\end{array}$ \\
\hline & $\begin{array}{l}\text { Apakah kamu menemukan kesulitan dalam memahami } \\
\text { unsur-unsur yang diketahui dan ditanyakan dari soal } \\
\text { tersebut? Coba jelaskan! }\end{array}$ \\
\hline & $\begin{array}{l}\text { Bagaimana cara kamu menemukan suku yang tidak terdapat } \\
\text { di antara barisan?Coba jelaskan! }\end{array}$ \\
\hline \multirow{3}{*}{ Menarik kesimpulan logis } & $\begin{array}{l}\text { Apa saja yang diketahui dan ditanyakan dari soal tersebut? } \\
\text { Coba jelaskan! }\end{array}$ \\
\hline & $\begin{array}{l}\text { Apakah kamu menemukan kesulitan dalam memahami } \\
\text { unsur-unsur yang diketahui dan ditanyakan dari soal } \\
\text { tersebut? Coba jelaskan! }\end{array}$ \\
\hline & $\begin{array}{l}\text { Bagaimana cara kamu menarik kesimpulan dan menentukan } \\
\text { nilai kebenarannya?Coba jelaskan! }\end{array}$ \\
\hline
\end{tabular}


Wawancara juga dilakukan pada guru mata pelajaran matematika dari kelas yang dijadikan sebagai subjek penelitan. Wawancara ini dilakukan apabila terdapat masalah yang diungkapkan oleh siswa yang berkaitan dengan proses pembelajaran yang dilakukan oleh guru. Tujuan dari wawancara ini adalah untuk mengkonfirmasi dan menggali informasi mengenai hal-hal yang berkaitan dengan proses pembelajaran yang dilakukan guru di kelas terkait materi pola bilangan.

Uji validitas instrumen tes siswa pada penelitian ini menggunakan validitas konstruksi. Validitas konstruksi bertujuan untuk menentukan berfungsi tidaknya suatu soal mengukur aspek yang hendak diukur (kemampuan penalaran matematis siswa) berdasarkan kriteria yang telah ditentukan, dalam hal ini adalah kriteria materi, konstruk, dan bahasa. Perhitungan validitas penilaian panelis menggunakan rumus dari Aiken (Adawia, 2016: 28) sebagai berikut:

$$
V=\frac{\sum n_{i}\left|i-i_{0}\right|}{[N(c-1)]}
$$

Dengan,

$S_{i}^{2}=\frac{\sum X_{i}^{2}-\frac{\left(\sum X_{i}\right)^{2}}{N}}{N}$ dan $S_{t}^{2}=\frac{\sum X_{t}^{2}-\frac{\left(\sum X_{t}\right)^{2}}{N}}{N}$

Keterangan:

$r_{11} \quad=$ Reliabilitas yang dicari

$n \quad=$ Banyak butir soal item/soal

$\sum S_{i}^{2}=$ Jumlah variansi skor tiap butir

$S_{t}^{2} \quad=$ variansi total

$X_{i} \quad=$ Skor ke-i tiap butir soal

$X_{t} \quad=$ Skor total tiap butir soal

$N=$ Banyaknya responden

Selanjutnya pemberian interpretasi terhadap koefisien reliabilitas tes $r_{11}$ pada umumnya digunakan patokan Guilford (Jihad dan Haris, 2013: 181):

$0 \leq r_{11} \leq 0,20$

reliabilitas: sangat rendah

$0,20<r_{11} \leq 0,40$

reliabilitas: rendah

$0,40<r_{11} \leq 0,70$

reliabilitas: sedang

$0,70<r_{11} \leq 0,90$

reliabilitas: tinggi
Keterangan:

$V \quad=$ Indeks validitas isi

$n_{i} \quad=$ Cacah dari titik skala hasil

penilaian rater

$i \quad=$ Titik skala ke-i $(\mathrm{i}=1,2,3,4$,

5)

$i_{0} \quad=$ Titik skala terendah

$N \quad=$ Jumlah rater

$c \quad=$ Banyaknya titik skala

Nilai $V$ terletak antara 0 dan 1 (dikatakan valid apabila nilai $V \geq 0,6$ ).

Butir soal yang valid digunakan dalam penelitian ini sedangkan butir soal yang tidak valid didrop.

Analisis reliabilitas instrumen untuk mengetahui sejauh mana konsep yang disusun menggambarkan keadaan sesungguhnya. Untuk menentukan ketepatan butir instrumen menggunakan rumus Alpha Cronbach (Jihad dan Haris, 2013: 180) sebagai berikut:

$$
r_{11}=\left(\frac{n}{n-1}\right)\left(1-\frac{\sum S_{i}^{2}}{S_{t}^{2}}\right)
$$

$$
\begin{aligned}
& 0,90<r_{11} \leq 1,00 \\
& \text { reliabilitas: sangat tinggi }
\end{aligned}
$$

Tes yang digunakan dalam penelitian ini adalah tes dengan nilai reliabilitas minimal kategori sedang.

Adapun metode pengumpulan data yang digunakan dalam penelitian ini adalah tes tertulis dan wawancara. Wawancara dengan siswa dimaksudkan untuk mengkonfirmasi ulang proses pengerjaan tes tertulis dari subjek penelitian sehingga dapat diketahui lebih lanjut terkait cara atau pola berpikir subjek terhadap kemampuan penalaran matematis dari soal tes tertulis yang telah diberikan. Peneliti melakukan wawancara kepada 8 orang perwakilan siswa kelas VIII $_{C}$ yakni 4 orang laki-laki dan 4 orang perempuan. Jenis wawancara yang dilakukan adalah wawancara tidak terstruktur dengan menggunakan pedoman wawancara yang mencakup garis besar pertanyaan yang disampaikan peneliti kepada siswa. Terdapat lima garis besar pertanyaan yang telah dirumuskan oleh peneliti. Dimulai dari siswa 
yang diminta untuk menjelaskan proses generalisasi untuk memperkirakan jawaban hingga menarik kesimpulan.

Walaupun demikian, kegiatan wawancara tidak hanya berpusat pada lima garis besar pertanyaan yang telah dirumuskan, dalam artian jika dalam kegiatan wawancara ada jawaban siswa yang memunculkan permasalahan baru dan berkaitan dengan penelitian, maka peneliti dapat menyampaikan pertanyaan baru yang belum disediakan. Pedoman wawancara yang disusun juga dilakukan pengujian validasi secara konstruk, dengan menggunakan pendapat dari ahli (judgement experts).Bentuk data yang diperoleh dalam penelitian ini adalah data hasil tes dan wawancara. Data hasil tes berupa kemampuan penalaran matematis siswa. Sedangkan, data hasil wawancara berupa konfirmasi ulang proses pengerjaan tes tertulis untuk mengetahui lebih lanjut terkait cara atau pola berpikir subjek penelitian terhadap kemampuan penalaran matematis dari tes yang diberikan, serta sejauh mana kemampuan siswa dalam menyelesaikan soal-soal cerita yang diberikan guru selama pembelajaran di kelas terkait materi Teorema Pola bilangan.

Data yang valid dapat diperoleh dengan melakukan uji kredibilitas (validitas interbal) terhadap data hasil penelitian sesuai dengan prosedur uji kredibilitas data dalam penelitian kualitatif. Adapun macam-macam pengujian kredibilitas menurut Sugiyono (2016: 368) antara lain dilakukan dengan perpanjangan pengamatan, peningkatan ketekunan dalam penelitian, triangulasi, diskusi dengan teman sejawat, analisis kasus negatif, dan membercheck.

Dalam pengujian keabsahan data, metode penelitian kualitatif menggunakan validitas internal (credibility) pada aspek nilai kebenaran, pada penerapannya ditinjau dari validitas eksternal (transferability), dan realibilitas (dependability) pada aspek konsistensi, serta obyektivitas (confirmability) pada aspek naturalis (Sugiyono, 2016: 366). Pada penelitian kualitatif, tingkat keabsahan lebih ditekankan pada data yang diperoleh. Melihat hal tersebut maka kepercayaan data hasil penelitian dapat dikatakan memiliki pengaruh signifikan terhadap keberhasilan sebuah penelitian. Data yang valid dapat diperoleh dengan melakukan uji kredibilitas (validitas internal) terhadap data hasil penelitian sesuai dengan prosedur uji kredibilitas data dalam penelitian kualitatif. Adapun macammacam pengujian kredibilitas menurut Sugiyono (2016: 368) antara lain dilakukan dengan perpanjangan pengamatan, peningkatan ketekunan dalam penelitian, triangulasi, diskusi dengan teman sejawat, analisis kasus negatif, dan membercheck.

Pengecekan keabsahan data dalam penelitian ini dengan menggunakan triangulasi. Triangulasi merupakan teknik yang mencari pertemuan pada satu titik tengah informasi dari data yang terkumpul guna pengecekan dan pembanding terhadap data yang telah ada. Terdapat 3 triangulasi dalam mengecek keabsahan data, yaitu triangulasi sumber, triangulasi teknik dan triangulasi waktu. Triangulasi dalam penelitian ini adalah triangulasi teknik, yaitu dengan membandingkan data hasil tes yang diverifikasi dengan hasil wawancara.

Penelitian ini adalah penelitian deskriptif dengan teknik analisis model Miles dan Huberman. Setelah datanya terkumpul, datanya direduksi sehingga akan memberikan gambaran lebih jelas dan memudahkan untuk melakukan pengumpulan data selanjutnya. Data diklasifikasikan menjadi dua kelompok, yakni data kuantitatif yang berbentuk angka-angka dan data kualitatif yang dinyatakan dalam bentuk kata-kata atau simbol. Data kualitatif yang berbentuk kata-kata tersebut disisihkan untuk sementara, karena akan sangat berguna untuk menyertai dan melengkapi gambaran yang diperoleh dari analisis data kuantitatif (Arikunto, 2006: 239-240). Data yang sudah direduksi maka langkah selanjutnya adalah menyajikan data. Penyajian data digunakan untuk lebih meningkatkan pemahaman kasus dan sebagai acuan mengambil tindakan berdasarkan pemahaman dan analisis sajian data. Penarikan simpulan merupakan hasil penelitian yang menjawab fokus penelitian yang disajikan dalam benuk deskriptif. Adapun data kualitatif dalam penelitian ini adalah hasil wawancara yang dilakukan kepada siswa. Sedangkan data kuantitatif dalam penelitian ini adalah hasil tes untuk kemampuan penalaran matematis siswa. Data ini akan dianalisis dengan cara sebagai berikut.

Penelitian ini adalah penelitian deskriptif. Apabila datanya telah terkumpul, 
maka data Data ini dianalisis dengan cara analisis data tes tertulis dan analisis data wawancara. Data tes tertulis siswa akan diberi skor pada tiap butir soal yang telah dikerjakan oleh siswa. Pemberian skor pada tiap butir soal disesuaikan dengan pendoman penskoran tiap butir soal yang telah ditentukan sebelumnya. Pedoman penskoran yang digunakan dapat dilihat pada Tabel 3 .

Tabel 3

Pedoman Penskoran Penalaran Matematis Siswa

\begin{tabular}{|c|l|c|}
\hline No. & \multicolumn{1}{|c|}{ Kriteria } & \multicolumn{1}{|c|}{ Skor } \\
\hline 1 & Respon (penyelesaian) diberikan secara lengkap dan benar. & 4 \\
\hline 2 & $\begin{array}{l}\text { Respon (penyelesaian) diberikan dengan satu kesalahan/ kekurangan yang } \\
\text { signifikan. }\end{array}$ & 3 \\
\hline 3 & $\begin{array}{l}\text { Respon (penyelesaian) benar secara parsial dengan lebih dari satu } \\
\text { kesalahan/kekurangan yang signifikan. }\end{array}$ & 2 \\
\hline 4 & $\begin{array}{l}\text { Respon (penyelesaian) tidak terselesaikan secara keseluruhan namun mengandung } \\
\text { sekurang-kurangnya satu argumen benar. }\end{array}$ & 1 \\
\hline 5 & $\begin{array}{l}\text { Respon (penyelesaian) berdasarkan pada proses atau argumen yang salah, atau tidak } \\
\text { ada respon sama sekali. }\end{array}$ & 0 \\
\hline
\end{tabular}

Setelah diberikan skor untuk tiap butir soal maka nilai yang diperoleh tiap siswa akan dihitung menggunakan rumus berikut:

$$
\text { Nilai Akhir }(N A)=\frac{\text { Skor perolehan }}{\text { Skor maksimum }} \times 100
$$

Rentang nilai yang diperoleh siswa adalah 0-100. Selanjutnya untuk melihat kriteria kemampuan penalaran yang dimiliki siswa maka nilai tes kemampuan penalaran matematis akan dikonversikan dalam dua kategori, yaitu kategori siswa dengan kemampuan di atas rata-rata dan di bawah rata-rata. Adapun cara menghitung rata-rata nilai siswa adalah sebagai berikut:

$$
\bar{X}=\frac{\sum X}{N}
$$

(Thompson, 2006)

dimana, diperoleh

$\bar{X} \quad=$ Nilai rata-rata yang diperoleh

$\Sigma X=$ Jumlah semua nilai yang

$N \quad=$ Banyaknya siswa

Dari perhitungan tersebut, diperoleh range nilai akhir dan kategori kemampuan seperti pada tabel 4 .

Tabel 4

Pengelompokan Kemampuan

Penalaran Matematis Berdasarkan Perolehan Nilai Akhir

\begin{tabular}{|c|c|}
\hline Nilai Akhir & Kategori Kemampuan \\
\hline $86-100$ & Sangat tinggi \\
\hline $76-85$ & Tinggi \\
\hline $66-75$ & Sedang \\
\hline$<65$ & Rendah \\
\hline
\end{tabular}

(Yulianti, 2010: 24)

Selanjutnya, dari setiap kategori kemampuan akan dipilih 8 siswa dengan ketentuan 4 siswa laki-laki dan 4 siswa perempuan sebagai subjek penelitian. Namun, sebelum subjek penelitian dari setiap kategori tersebut dipilih terlebih dahulu nilai akhir semua siswa dari masing-masing kategori dibedakan antara nilai siswa laki-laki dan siswa perempuan. Kemudian nilai yang sudah dibedakan tersebut diurutkan, mulai dari nilai yang tertinggi sampai nilai yang terendah. Dari masing-masing kategori dipilih 1 siswa laki-laki dan 1 siswa perempuan dengan cara mengambil nilai siswa yang menengah. Kemudian hasil pekerjaan tes tertulis dari tiap subjek penelitian tersebut akan dianalisis dan disajikan dalam 
bentuk deskripsi yang didasarkan pada 4 langkah penalaran menurut Polya. Tahap selanjutnya subjek penelitian juga akan diwawancarai untuk mengetahui lebih lanjut terkait cara atau pola berpikir dalam hal kemampuan penalaran yang dimilikinya.

Data hasil wawancara yang diperoleh dianalisis secara deskriptif yakni dengan menyimpulkan jawaban siswa selama proses wawancara berlangsung. Hal ini dilakukan dengan cara membuat transkrip wawancara dari hasil wawancara tiap subjek penelitian. Selanjutnya di ambil poin-poin penting dari transkrip wawancara tersebut untuk mengkonfirmasi ulang proses pengerjaan tes tertulis sehingga dapat diketahui lebih lanjut terkait cara atau pola berpikir subjek terhadap kemampuan penalaran matematis dari soal tes yang diberikan.

\section{Hasil}

Hasil analisis deskriptif nilai tes kemampuan penalaran matematis siswa kelas VIII $_{\mathrm{C}}$ SMP Negeri 5 Kendari yang diolah dengan Ms. Excel 2010 dapat dilihat pada Tabel 5 .

Tabel 5

Analisis Deskriptif Nilai Kemampuan

Penalaran Matematis Siswa Kelas VIII

\begin{tabular}{|l|r|}
\hline \multicolumn{2}{|c|}{ Nilai Akhir } \\
\hline Mean & 46,79 \\
\hline Median & 39,29 \\
\hline Mode & 35,71 \\
\hline Standard Deviation & 19,34 \\
\hline Sample Variance & 374,23 \\
\hline Range & 67,86 \\
\hline Minimum & 21,43 \\
\hline Maximum & 89,29 \\
\hline
\end{tabular}

Berdasarkan Tabel 3 dapat dilihat rata-rata. Selain itu, diperoleh varians sama dengan 374,23; range sama dengan 67,86; nilai minimum sama dengan 21,43; dan nilai maksimum sama dengan 89,29.

Hasil analisis deskriptif nilai tes kemampuan penalaran matematis siswa laki-laki dan siswa perempuan kelas VIII $_{\mathrm{C}}$ SMP Negeri 5 Kendari yang diolah dengan Ms. Excel 2010 dapat dilihat pada Tabel 6.

Tabel 6

Analisis Deskriptif Nilai Kemampuan Penalaran Matematis Siswa Laki-Laki dan Siswa Perempuan Kelas VIII

\begin{tabular}{|l|r|r|}
\hline \multicolumn{1}{|c|}{ Nilai Akhir } & Laki-Laki & Perempuan \\
\hline Mean & 45,71 & 48,47 \\
\hline Median & 35,71 & 39,29 \\
\hline Mode & 32,14 & 39,29 \\
\hline Standard Deviation & 19,99 & 20,53 \\
\hline Sample Variance & 399,42 & 421,32 \\
\hline Range & 60,71 & 67,86 \\
\hline Minimum & 28,57 & 21,43 \\
\hline Maximum & 89,29 & 89,29 \\
\hline
\end{tabular}

Sedangkan rata-rata, median, dan modus perempuan berturut-turut adalah 48,$47 ; 39,29$; hasil tes kemampuan penalaran matematis siswa dan 39,29. Dari kedua data tersebut diketahui 
nilai mean, median dan modus yang saling berdekatan, sehingga data berdistribusi normal artinya data dapat mewakili nilai anggotaanggota dalam kelompok. Kemudian dari nilai rata-rata, median dan modus ini, juga terlihat bahwa data siswa perempuan lebih berdistribusi normal dibandingkan dengan data siswa lakilaki. Selain itu, dapat dilihat pula bahwa kemampuan penalaran matematis siswa perempuan lebih tinggi dibandingkan siswa lakilaki. Standar deviasi dan varians hasil tes kemampuan penalaran matematis siswa laki-laki berturut-turut adalah 19,99; dan 399,42. Sedangkan standar deviasi dan varians hasil tes kemampuan penalaran matematis siswa perempuan berturut-turut adalah 20,53; dan 421,32. Hal ini menunjukkan bahwa kemampuan penalaran matematis pada siswa perempuan lebih beragam, dalam arti bahwa kemampuan penalaran matematis siswa perempuan menyebar lebih jauh dari rata-rata dibandingkan siswa laki-laki. Dengan kata lain, siswa perempuan yang memiliki kemampuan tinggi dan siswa perempuan yang memiliki kemampuan rendah memiliki selisih yang lebih besar dibandingkan dengan siswa laki-laki. Selain itu, diperoleh range, nilai minimum, dan nilai maksimum hasil tes kemampuan penalaran matematis siswa laki-laki berturut-turut adalah 60,$71 ; 28,57$; dan 89,29 . Sedangkan range, nilai minimum, dan nilai maksimum hasil tes kemampuan penalaran matematis siswa perempuan berturut-turut adalah 67,$86 ; 21,43$ dan 89,29 . Sehingga, pemilihan subjek untuk setiap kategori dapat mewakili setiap data dalam kategori itu..

Pengelompokan kemampuan penalaran didasarkan pada nilai rata-rata kemampuan penalaran matematis siswa yang dikonversikan dalam empat kategori, yaitu kategori siswa dengan kemampuan penalaran matematis sangat tinggi, tinggi, sedang dan rendah seperti yang disajikan pada Tabel 7.

Tabel 7

Daftar Nilai dan Pengelompokan Kriteria Kemampuan Penalaran Matematis Siswa

\begin{tabular}{|c|c|c|c|c|}
\hline Nama Siswa (L/P) & Nilai & Kriteria Kemampuan & $\begin{array}{l}\text { Total } \\
\text { Siswa }\end{array}$ & Presentase \\
\hline Annisa Zhafirah R. (P) & 89,29 & \multirow{2}{*}{ Sangat Tinggi } & \multirow[t]{2}{*}{2} & \multirow{2}{*}{$6,4 \%$} \\
\hline Thoriq Kemal Abillah (L) & 89,29 & & & \\
\hline Laode. Muh. Surya Putra (L) & 82,14 & \multirow[t]{3}{*}{ Tinggi } & \multirow[t]{3}{*}{3} & \multirow[t]{3}{*}{$9,7 \%$} \\
\hline Popon Fadlia Putri (P) & 78,57 & & & \\
\hline Masita R. (P) & 78,57 & & & \\
\hline Rafli Prayuda (L) & 75 & \multirow[t]{2}{*}{ Sedang } & \multirow[t]{2}{*}{2} & \multirow[t]{2}{*}{$6,4 \%$} \\
\hline Nur Angraeni Syam (P) & 67,86 & & & \\
\hline Amanda Aulia Putri (P) & 64,29 & \multirow{18}{*}{ Rendah } & \multirow{18}{*}{24} & \multirow{18}{*}{$77,5 \%$} \\
\hline Muhammad Arjuna (L) & 50 & & & \\
\hline Adelia Nindia Sari M. (P) & 50 & & & \\
\hline Ryan Hidayatullah (L) & 46,43 & & & \\
\hline Yehuda Ricki Lawolyo (L) & 42,86 & & & \\
\hline Adelia Ardani (P) & 42,86 & & & \\
\hline Qadri Nur Aqeela Jhon (P) & 39,29 & & & \\
\hline Rizky Amelia (P) & 39,29 & & & \\
\hline Tiara Wirdadinaka $(\mathrm{P})$ & 39,29 & & & \\
\hline Almunajat Amirul S. (L) & 39,29 & & & \\
\hline Saharudin (L) & 35,71 & & & \\
\hline Muharam (L) & 35,71 & & & \\
\hline Muh. Yusuf (L) & 35,71 & & & \\
\hline Nur Asmiati (P) & 35,71 & & & \\
\hline Vika Nur Faiza (P) & 35,71 & & & \\
\hline Alif Muhammad Ilham (L) & 32,14 & & & \\
\hline Akbar (L) & 32,14 & & & \\
\hline Arham Halulanga (L) & 32,14 & & & \\
\hline
\end{tabular}




\begin{tabular}{|l|c|c|c|}
\hline Mega Deviana (P) & 32,14 & \multirow{5}{*}{} & \\
\hline Abriatmo Mahmud (L) & 28,57 \\
\hline Laode Al Razak (L) & 28,57 \\
\hline Abdullah Mustamin (L) & 25 & & \\
\hline Ambar Wati (P) & 25 & & \\
\hline Gasya Septi Kayla I. (P) & 21,43 & & \\
\hline
\end{tabular}
pengelompokan kemampuan penalaran matematis yang dimiliki siswa, peneliti memilih 8 sampel siswa sebagai subjek penelitian. Sampel yang dipilih adalah 2 siswa yang terdiri dari 1 siswa laki-laki dan 1 siswa perempuan dari kriteria kemampuan penalaran matematis sangat tinggi. 2 siswa yang terdiri dari 1 siswa laki-laki dan 1 siswa perempuan dari kriteria kemampuan penalaran matematis tinggi, 2 siswa

yang terdiri dari 1 siswa laki-laki dan 1 siswa perempuan dari kriteria kemampuan penalaran matematis sedang dan 2 siswa lainnya yang terdiri dari 1 siswa laki-laki dan 1 siswa perempuan dari kriteria kemampuan penalaran matematis rendah. Namun, sebelum subjek penelitian dari setiap kategori tersebut dipilih terlebih dahulu nilai akhir semua siswa dari masing-masing kategori dibedakan antara nilai siswa laki-laki dan siswa perempuan.

Tabel 8

Daftar Nilai Tes Kemampuan Penalaran Matematis Siswa Laki-Laki dan Siswa Perempuan

\begin{tabular}{|c|c|c|c|}
\hline \multicolumn{2}{|c|}{ Siswa Laki-Laki } & \multicolumn{2}{|c|}{ Siswa Perempuan } \\
\hline Nama & Nilai & Nama & Nilai \\
\hline Abdullah Mustamin & 25 & Adelia Ardani & 42,86 \\
\hline Abriatmo Mahmud & 28,57 & Adelia Nindia Sari M. & 50 \\
\hline Alif Muhammad Ilham & 32,14 & Amanda Aulia Putri & 64,28 \\
\hline Almunajat Amirul S. & 39,28 & Annisa Zhafirah R. & 89,28 \\
\hline Akbar & 32,14 & Gasya Septi Kayla I. & 21,43 \\
\hline Arham Halulanga & 32,14 & Masita R. & 78,57 \\
\hline Ld. Muh. Surya Putra & 82,14 & Mega Deviana & 32,14 \\
\hline Ld. Al Razak & 28,57 & Nur Angraeni Syam & 67,86 \\
\hline Muhammad Arjuna & 50 & Nur Asmiati & 35,71 \\
\hline Muharam & 35,71 & Popon Fadlia Putri & 78,57 \\
\hline Rafli Prayuda & 75 & Qadri Nur Aqeela Jhond & 39,28 \\
\hline Ryan Hidayatullah & 46,43 & Rizky Amelia & 39,28 \\
\hline Saharudin & 35,71 & Tiara Wirdadinaka & 39,28 \\
\hline Thoriq Kemal Abillah & 89,28 & Vika Nur Faiza & 35,71 \\
\hline Yehuda Ricki L. & 42,86 & Ambar Wati & 25 \\
\hline
\end{tabular}

Dari masing-masing kategori dipilih 1 paling tinggi kemudian didiskusikan dengan siswa laki-laki dan 1 siswa perempuan dengan cara mengambil nilai tes kemampuan penalaran siswa yang paling rendah, sedang, tinggi dan guru mata pelajaran subjek-subjek yang dipilih. Subjek penelitian yang dipilih diberi kode seperti pada Tabel 9.

Tabel 9

Subjek Penelitian

\begin{tabular}{|c|l|}
\hline Kriteria Kemampuan Penalaran & \multicolumn{1}{c|}{ Subjek Penelitian } \\
\hline Sangat Tinggi & Thoriq Kemal Abillah (L) \\
\cline { 2 - 2 } & Annisa Zhafirah Ramadhany (P) \\
\hline \multirow{2}{*}{ Tinggi } & Laode Muh. Surya Putra (L) \\
\cline { 2 - 2 } & Popon Fadlia Putri (P) \\
\hline
\end{tabular}




\begin{tabular}{|l|l|}
\hline \multirow{2}{*}{ Sedang } & Rafli Prayuda $(\mathrm{L})$ \\
\cline { 2 - 2 } & Nur Angraeni Syam $(\mathrm{P})$ \\
\hline \multirow{2}{*}{ Rendah } & Akbar $(\mathrm{L})$ \\
\cline { 2 - 2 } & Qadri Nur Aqeela $(\mathrm{P})$ \\
\hline
\end{tabular}

Selain analisis hasil pekerjaan siswa sebagai subjek penelitian, peneliti juga melakukan analisis hasil wawancara dengan subjek penelitian. Hal ini bertujuan untuk mengkonfirmasi ulang proses yang dilakukan subjek penelitian untuk menyelesaikan soal tes kemampuan penalaran matematis yang diberikan. Selain itu, untuk mengetahui lebih lanjut terkait cara atau pola berpikir subjek terhadap kemampuan penalaran matematis dari soal tes yang diberikan. Selain analisis terhadap siswa sebagai subjek penelitian, peneliti juga melakukan analisis hasil wawancara dengan guru mata pelajaran matematika. Hal ini bertujuan untuk mengkonfirmasi kesulitan siswa dalam mengerjakan soal materi pola bilangan, dan mengkonfirmasi kesiapan siswa yang akan dijadikan sebagai subjek wawancara.

Berdasarkan analisis hasil tes tertulis dan wawancara, terlihat bahwa ada perbedaan kemampuan penalaran matematis antara siswa laki-laki dan siswa perempuan dari masingmasing nomor soal. perbedaan tersebut dapat dilihat dari 4 indikator penalaran yakni menyajikan pernyataan matematis secara lisan, tertulis, gambar dan diagram; menemukan pola atau sifat dari gejala matematis untuk membuat generalisasi; memperkirakan jawaban dan proses solusi; dan menarik kesimpulan logis.

\section{Pembahasan}

Setelah dilakukan deskripsi hasil analisis tes tertulis siswa, maka untuk mengecek keabsahan data maka dilakukan triangulasi teknik pengumplan data melalui tahap wawancara. Berdasarkan hasil analisis wawancara, diperoleh gambaran bahwa secara umum siswa dapat menjelaskan lebih jauh tentang langkah-langkah menyelesaikan soalsoal penalaran yang telah diberikan. Adapun siswa yang tidak menjawab soal bagian tertentu dikarenakan guru belum membahas terlalu jauh materi yang bersangkutan. Selain itu, terdapat siswa yang mengosongkan beberapa nomor pada lembar jawaban, setelah dikonfirmasi disebabkan oleh keterbatasan waktu, karena siswa terpatok pada soal-soal yang susah.
Berdasarkan deskripsi data tes tertulis yang dilengkapi wawancara, dapat dipaparkan bagaimana kemampuan penalaran matematis yang dimiliki oleh siswa laki-laki dan siswa perempuan.

Berdasarkan hasil pembahasan yang telah dipaparkan, maka hasil yang diperoleh memiliki kesesuaian dengan kajian teori bab II. Teori perbedaan gender menurut Elliot (De Carvalho, 2017: 52-53) mengatakan bahwa kemampuan verbal siswa perempuan lebih bagus dibandingkan dengan laki-laki yang berarti bahwa kemampuan penalaran matematis siswa perempuan lebih tinggi dibandingkan siswa lakilaki. Sejalan dengan teori tersebut, berdasarkan hasil analisis diperoleh bahwa kemampuan penalaran matematis siswa perempuan lebih tinggi dibandingkan siswa laki-laki. Sehingga, siswa perempuan lebih baik dalam melakukan penalaran dari soal yang diberikan dengan menerjemahkan maksud dari soal tersebut ke dalam unsur-unsur yang terdapat dalam indicator penalaran.

Selain itu, teori lain menurut Krutetski (Nafi'an, 2011: 573-574) mengatakan bahwa kemampuan matematika dan mekanika siswa laki-laki lebih baik daripada siswa perempuan. Sejalan dengan hal itu hasil penelitian Donna dan Martha (1997: 320) menunjukkan bahwa perbedaan kemampuan metakognisi antara siswa laki-laki dan perempuan yaitu pengetahuan tentang penggunaan strategi pemecahan masalah matematika. Berdasarkan perbedaan karakteristik antara siswa laki-laki dan perempuan, diduga siswa laki-laki mempunyai aktivitas metakognisi yang berbeda dibandingkan siswa perempuan. Namun, pada kenyataannya diperoleh bahwa kemampuan matematika siswa perempuan lebih tinggi dibandingkan siswa laki-laki. Hal ini dapat dipengaruhi oleh beberapa faktor. Hal ini juga didasari oleh teori yang mengatakan bahwa perempuan lebih baik dalam kebenaran, ketelitian, kecermatan, dan keseksamaan berpikir. Sehingga, dalam menyelesaikan soal matematika siswa perempuan lebih baik dalam menggunakan rumus apa saja yang dibutuhkan dalam menyelesaikan soal yang diberikan. 
Selain itu, siswa perempuan juga lebih teliti dan cermat dalam melakukan perhitungan pada tiap penyelesaian soal yang diberikan. Hal ini dikarenakan siswa perempuan lebih baik dalam menghafal dan memahami rumus-rumus matematika. Selain itu, siswa perempuan juga lebih mampu menjelaskan secara rinci mengenai rumus yang digunakan dalam penyelesaian soal yang diberikan dibandingkan siswa laki-laki.

\section{Simpulan dan Saran}

\section{Simpulan}

Berdasarkan hasil penelitian dan pembahasan, maka kesimpulan dalam penelitian ini adalah secara keseluruhan, siswa perempuan unggul pada indikator menyajikan pernyataan matematis secara lisan, tertulis, gambar dan diagram dan juga indikator memperkirakan jawaban dan proses solusi. Siswa laki-laki unggul pada indikator menarik kesimpulan logis. Sedangkan pada indikator menemukan pola atau sifat dari gejala matematis untuk membuat generalisasi kemampuan siswa laki-laki dan siswa perempuan relative sama. Sehingga kemampuan penalaran matematis siswa perempuan lebih unggul daripada kemampuan penalaran siswa laki-laki.

\section{Saran}

Berdasarkan hasil penelitian dan pembahasan yang telah diuraikan, maka dapat dikemukakan beberapa saran sebagai berikut.

1. Perlu dilakukan penelitian lanjutan untuk melihat kemampuan penalaran matematis siswa pada level sekolah yang berbeda.

2. Bagi peneliti-peneliti berikutnya dapat mengembangkan penelitian ini, dengan mengkolaborasikan kemampuan penalaran matematis dengan pendekatan pembelajaran yang berkaitan.

\section{Daftar Pustaka}

Adawia. (2016). Deskripsi Perbedaan Pengetahuan Dasar Matematika Siswa Kelas VII SMP Negeri dan SMP Swasta di Kota Kendari Tahun Pelajaran 2016/2017. Skripsi. Program Sarjana Pendidikan Matematika Universitas Halu Oleo. Kendari.
Afandi, A. (2016). Profil Penalaran Deduktif Siswa SMP dalam Menyelesaikan Masalah Geometri Berdasarkan Perbedaan Gender. Jurnal Apotema, Vol. 2, No. 1, 2016, hal: 1-14.

Arikunto, S. (2006). Prosedur Penelitian Suatu Pendekatan Praktek. PT Asdi Mahasatya. Jakarta.

Ario, M. (2016). Analisis Kemampuan Penalaran Matematis Siswa SMK Setelah Mengikuti Pembelajaran Berbasis Masalah. Jurnal Penelitian Pendidikan Matematika FKIP Universitas Pasir Pengaraian, Vol. 5 No. 2, 2016, hal: 125-135.

Carvalho, S. F. L. D. (2017). Analisis Kemampuan Siswa dalam Pemecahan Masalah Berbentuk Soal Cerita pada Pembelajaran Matematika Ditinjau dari Segi Gender pada Materi Segiempat Siswa Kelas VII F SMP Negeri 1 Seyegan. Skripsi. Program Sarjana Program Studi Pendidikan Matematika Universitas Sanata Dharma. Yogyakarta.

Effendi, L. A. (2012). Pembelajaran Matematika dengan Metode Penemuan Terbimbing untuk Meningkatkan Kemampuan Representasi dan Pemecahan Masalah Matematis Siswa SMP. Jurnal Penelitian Pendidikan Matematika Sekolah Pascasarjana UP.. Vol 13, No. 2, 2012, hal: 1-10.

Kurniawaty, A. (2017). Analisis Kemampuan Literasi Matematis Siswa SMP Pesisir Konawe Utara Ditinjau dari Perbedaan Gender. Tesis. Program Pascasarjana Pendidikan Matematika Universitas Halu Oleo (UHO). Kendari.

Mullis, Ina V.S, Martin, O. Michael dan Foy Pierre. (2012). TIMSS 2011 International Results in Mathematics. Chestnet Hill United States: Lynch School of Education Boston College.

Nafi'an, M. I. (2011). Kemampuan Siswa Dalam Menyelesaikan Soal Cerita Ditinjau Dari Gender Di Sekolah Dasar. Prosiding Seminar

Nasional Matematika dan Pendidikan M atematika Yogyakarta: 571-577. 